This item was submitted to Loughborough's Research Repository by the author.

Items in Figshare are protected by copyright, with all rights reserved, unless otherwise indicated.

\title{
Book Review: Mid-century modern interiors: The ideas that shaped interior design in America, by Lucinda Kaukas Havenhand
}

PLEASE CITE THE PUBLISHED VERSION

https://doi.org/10.1080/14606925.2019.1629056

\section{PUBLISHER}

(C) Taylor \& Francis (Routledge)

\section{VERSION}

AM (Accepted Manuscript)

\section{PUBLISHER STATEMENT}

This is an Accepted Manuscript of an article published by Taylor \& Francis in Design Journal on 04 Jul 2019, available online: https://doi.org/10.1080/14606925.2019.1629056

\section{LICENCE}

CC BY-NC-ND 4.0

\section{REPOSITORY RECORD}

Edwards, Clive. 2019. "Book Review: Mid-century Modern Interiors: The Ideas That Shaped Interior Design in America, by Lucinda Kaukas Havenhand". figshare. https://hdl.handle.net/2134/38229. 


\section{The Design Journal}

Review of

Mid-century modern interiors: The Ideas that shaped interior design in America by Lucinda Kaukas Havenhand

London: Bloomsbury 2019, 154 pp., 30 b/w illustrations, p/b ISBN 9781350045729, $£ 18.99$

--Manuscript Draft--

\begin{tabular}{|l|l|}
\hline Manuscript Number: & $\begin{array}{l}\text { Review of } \\
\text { Mid-century modern interiors: The Ideas that shaped interior design in America by } \\
\text { Lucinda Kaukas Havenhand } \\
\text { London: Bloomsbury 2019, 154 pp., 30 b/w illustrations, p/b ISBN 9781350045729, } \\
£ 18.99\end{array}$ \\
\hline Article Type: & Book/exhibition review \\
\hline Section/Category: & Art and Design \\
\hline Keywords: & interior design; philosophy \\
\hline Corresponding Author: & $\begin{array}{l}\text { Clive Edwards, PhD } \\
\text { Loughborough University } \\
\text { UNITED KINGDOM }\end{array}$ \\
\hline $\begin{array}{l}\text { Corresponding Author Secondary } \\
\text { Information: }\end{array}$ & \\
\hline Corresponding Author's Institution: & Loughborough University \\
\hline $\begin{array}{l}\text { Corresponding Author's Secondary } \\
\text { Institution: }\end{array}$ & \\
\hline First Author: & Clive Edwards, PhD \\
\hline First Author Secondary Information: & \\
\hline Order of Authors: & Clive Edwards, PhD \\
\hline Order of Authors Secondary Information: & \\
\hline Abstract: & \\
\hline
\end{tabular}


Mid-century modern interiors: The Ideas that shaped interior design in America by Lucinda Kaukas Havenhand

London: Bloomsbury 2019, 154 pp., 30 b/w illustrations, p/b ISBN 9781350045729 , $£ 18.99$

Lucinda Havenhand's Mid-Century Modern Interiors is a timely and useful work that illuminates the interior designs of some important American designers through discussion and evaluation of the inspirations and theories they drew upon. Interest in both interiors and products designed and made in the mid-twentieth century has been enormous in the recent past, A large number of books and websites have been produced which extol the virtues of "retro style" or "mid century modern" etc. Examples include Deborah Dietsch's Classic Modern: Midcentury Modern at Home (2000), Bradley Quinn's Mid-Century Modern: Interiors, Furniture, Design Details (2006), Dominic Bradbury's Mid-Century Modern Complete (2014) and Judith Miller's Living with Mid-Century Modern Design (2018). These are often highly illustrated works reproducing important (and often well-known) interior images that frequently consider aspects of style, but with little conceptual apparatus. Havenhand has taken a far more thoughtful approach to the subject and has provided readers with a valuable set of deeper insights into the influences that affected how these interiors came to look as they do.

The period 1930s to the 1960s was a significant moment for interior design practice as it saw the field develop into a profession distinct from interior decoration. Havenhand uses this idea as one of the underlying themes of her book. In the first pages she quotes influential MoMA curator Edgar Kaufmann jr.'s notion that interior design is concerned with "principles not effects"; i.e. concepts, not simply the visual. This idea is employed throughout the book as she uses it to unpick the principles behind five well-known designers' projects.

This methodology that steps back from the projects and objects aims "to bring to light the motivating ideas, philosophes and conceptual frameworks that fed these designers and created their unique perspectives". (Havenhand 2019, xv) This approach is assisted by the author's research methodology that is based on ethnographical, biographical, and inter-textual investigations. Although the roll call of names will be familiar: Ray and Charles Eames, George Nelson, Richard Neutra, Russel and Mary Wright, and Florence Knoll, Havenhand has successfully revealed some lesser-known aspects of their thinking and influences and importantly how this impacted on their work.

Havenhand's first case study is Russel and Mary Wright: Nostalgic Modern and the "American Way of Life". Russel is most well known for his American Modern dinnerware but the author has delved into other projects including his furniture and interiors. Their aim was nothing less than to attempt to express true American culture, its character, and values that were to be an alternative to imported European modernism. They had a desire to link a combination of American concepts of modernity and tradition, technology and craft, and diversity and unity, that all equated to their idea of "Americanism". This patriotism was particularly seen in the sales manual that accompanied the promotion of a range of goods titled American Way. These goods were "designed by Americans for Americans" and were planned to reflect the diversity of the country and its traditions. Unfortunately this complex project was not a success. The rest of the case study is developed from the Wrights' own Guide for Easier Living, published in 1950, which posited a 'new American way 
of life". Rejecting European modernism, as well as direct replications of past designs, they developed ideas of designs that tried to reflect American ideals of participatory democracy, freedom, and individuality. Havenhand explores their attempts to "design in" these ideas, in their publication and in their own homes, especially the famous Dragon Rock House. Although the work of the Wrights was often far removed from their stated ideals and was out of favour by the early 1950s, Havenhand points out that their re-conceptualised approach to home design did have a long-term impact, in terms of encouraging particular American interior design ideals of a combination of flexibility, informality and practicality.

In some contrast, the second study is of "Richard Neutra and the Therapeutic Interior". Havenhand discusses his biography and early work and influences which led to an architectural design style that "translated the vocabulary of International Style modern to meet the needs of [US] West Coast living" (Havenhand 2019, 40). The roll call of names that were a major influence upon him include Adolf Loos, Eric Mendelsohn, Rudolf Schindler, Frank Lloyd Wright and Sigmund Freud..

Following on from this particular approach, which had embraced technology and the organic to a degree, Neutra shifted focus towards considerations of well-being and the development of his own concept of bio-realism. This was essentially a deep concern and consideration of the physiological and psychological effects of design. Neutra explained his concept in his publication, Survival Through Design (1954). In a review of the book Sibyl Moholy-Nagy wrote: "It represents, among many other original tenets, the conviction that architects are intellectual people, and that they are willing to see their work in the largest possible context of man between amoeba and pure spirit". i She then goes on to say that anyone who knows practicing architects will doubt this premise. Nevertheless, Neutra tried to practice what he preached, even seeing himself as a "designer/doctor". He developed a personal rapport with each client, interviewed them, had them complete surveys of their functional and emotional needs, and then diagnosed a solution for them. In this regard, Havenhand points out how Neutra was influenced by psychologists such as the nineteenth century Wilhelm Wundt, who developed experimental psychology that studies the mind through empirical experiments. For Neutra, these experiments were made within the buildings and interiors he created.

Although best known for industrial design, graphic design, and film, Ray and Charles Eames feature as the third case study in this book. The essential idea that Havenhand draws out of these well-known designers is the concept of a 'New Language of Vision'. This idea was developed by the Eames's through the dual influences of Ray's artist mentor Hans Hofmann and their friend and colleague György Kepes. Kepes wrote a book titled The Language of Vision (1944) in which he argues that people need to be re-trained to see the world around them and crucially to be able to fully engage with it through a language of vision. Importantly, Kepes suggested that designers and architects played a key role in this process. Using the famous Eames House (Los Angeles) as a case study of this concept of 'language of vision' the author explores what the theories and practices of the two influences were, and how they became manifest as a 'living demonstration' in both the structure of the house and the presentation of its interiors and its 'functioning decoration'.

Another case study is of the designer George Nelson, again perhaps better known for products, raher than interiors. Here Havenhand considers the concepts of humanism, 
morality, and the Japanese aesthetic that influenced his work. Nelson himself proclaimed that humane environments were crucial, and therefore a humane approach to design was essential. He practiced this method through his concept of being a 'universal designer' who was not tied to a particular strand of design thinking. Havenhand identifies three diverse thinkers who made an impact on his ideas. These were the philosophers A.N. Whitehead, Ortega y Gasset and Eric Fromm. The author explains how these three influences developed Nelson's attitudes to life and design by emphasising the humane through a continual search for meaning and purpose in design. She then explains how he believed that design could then be an 'agent of transcendence, life enhancement, and promotion of a greater good' (Havenhand, 2019 , p.92). Havenhand quotes a good example of Nelson's humane approach, where he critiques Mies van der Rohe's Tugendhat House as being like a museum rather than a space for family living.

Nelson also developed a long-standing admiration for the Japanese aesthetic used in design and interiors that reflected the honest and natural, as well as ideas of surprise and delight. Havenhand explores the Japanese concept of wabi-sabi to illuminate some of Nelson's design work. This Japanese connection leads the author to suggest that Nelson had something of the Zen master about him that was expressed through his design work and writings.

The final study, titled The Interiors of Florence Schust Knoll: Structure, Luxury and Postwar America, considers the work and influences of Florence Knoll and her company that was responsible for many commercial interiors in the period that evidence a particular "Knoll Look". Like all the other case studies, the concept of "principles not effects" is evident in this example. Florence Knoll was imbued with the tenets of European modernism and total design of her mentors that included Eliel Saarinen, Walter Gropius, Mies van der Rohe and Hans Knoll. These were not directly philosophical influences rather they were designerly ones. Indeed this case study discusses her mentors and their individual approaches in some depth: Saarinen's idea of total design, Mies's emphasis on structure, and Hans Knoll's embracement of the Bauhaus ideal extolling the conjunction of art and industry. Her success was in the assimilation of these designers' concepts that subsequently created her own brand. It is therefore not surprising that particular German concepts were evident in her work as she distilled the ideas of the Gesamtkunstwerk (total work of art) of Kunstwollen (artistic will) and Moralischen Luxus (functional luxury/beauty) into her interiors. This case study therefore relies more heavily on a discussion of the work and idea of her mentors rather than Knoll herself.

Knoll's expressions of aesthetics and functions were mainly developed through commercial situations, unlike most of the other case studies where the designers were more often concerned with domestic living. However, the Knoll style or 'look' was ideal as an expression of a modern corporate workplace, and created a symbolism of success and prosperity for the clients.

In the conclusion, the author returns to the issue of "principles not effects" by reflecting upon the case studies that demonstrated the particular designers' intentions of representing the modern, and at the same time enhancing humanity through design and environment, by using interiors as a way to promote their principles to the public. She argues that with the rise of consumerism, the play of market forces, and the demand for novelty that occurred in the period following the "mid-century", the opportunity for interior designers to engage in similar ways of thinking and engaging 
with theories and ideas declined. She suggests that the mission for today's

contemporary designers is once again to rise to the challenges that require deep and committed thinking. In other words, working with "principles not effects".

Clive Edwards

Professor Emeritus

School of Arts

Loughborough University

United Kingdom

${ }^{\mathrm{i}}$ Moholy-Nagy, Sibyl. 1954. "Richard Neutra, Survival though Design". College Art Journal 13 (4): 329. 